\title{
What drives the development of community energy in Europe? The case of wind power cooperatives
}

Thomas Bauwens, Boris Gotchev and Lars Holstenkamp

Thomas Bauwens ${ }^{1}$, Environmental Change Institute, Oxford University Centre for the Environment, University of Oxford. South Parks Road, Oxford OX1 3QY, UK. Permanent address: Centre for Social Economy, HEC-ULg, Bvd du Rectorat 3, 4000 Liege, Belgium. Email: thomas.bauwens@ulg.ac.be

Boris Gotchev, Institute for Advanced Sustainability Studies Potsdam, Transdisciplinary Panel on Energy Change (TPEC). Professional address: Berliner Strasse 130 D-14467 Potsdam, Germany. Email: boris.gotchev@iass-potsdam.de

Lars Holstenkamp, Leuphana University of Lüneburg, Innovation Incubator \& Institute of Banking, Finance and Accounting. Professional address: Scharnhorststraße 1, C6.212, 21335 Lüneburg, Germany. Email: holstenkamp@uni.leuphana.de

This paper is an author post-print version of a paper accepted for publication in the journal Energy Research \& Social Science.

\footnotetext{
${ }^{1}$ Corresponding author.
} 


\title{
What drives the development of community energy in Europe? The case of wind power cooperatives
}

\author{
Thomas Bauwens, Boris Gotchev and Lars Holstenkamp
}

\begin{abstract}
:
The dominant model of energy infrastructure has historically been conceived in a very centralized fashion, i.e. with hardly any citizen involvement in energy generation. Yet, increasing attention is being paid to the transition process towards a more decentralized configuration. This article examines the factors likely to foster citizen and community participation as regards wind power cooperatives in Denmark, Germany, Belgium and the UK. Using Elinor Ostrom's Social-Ecological System Framework, the analysis highlights a double-edged phenomenon: prevailing and growing hostility towards cooperatives, on the one hand, and, on the other, strategic reactions to this evolution. What comes out indeed is that, throughout most of these countries, the emergence of some coordinated inter-organizational actions among cooperatives enables them to survive in their critical environment.
\end{abstract}

Keywords:

Wind power; cooperative; community energy; European comparison; citizen participation; social-ecological system. 


\section{Introduction}

The dominant model of energy infrastructure has historically been conceived as very centralized, with hardly any citizen involvement in energy production. Yet, an increasing number of scholars, citizens and policy-makers advocate the transition towards a more decentralized configuration, involving geographically dispersed and small-scale generation units located close to consumers [1]. Decentralized systems are said to present several advantages over centralized ones, including reduced costs for transmission and distribution systems, reduced grid power losses, more efficient data management systems and a larger share of zero-carbon technologies [2]. In turn, this configuration requires an active role from energy users, the latter becoming themselves "prosumers" or co-providers of energy services [3].

In this context, it is thus meaningful to study the factors likely to foster citizen participation. Community energy projects, i.e. formal or informal citizen-led initiatives which propose collaborative solutions on a local basis to facilitate the development of sustainable energy technologies, may have an important role to play in this respect. These initiatives are increasingly perceived as key potential actors in the transition toward low-carbon energy systems [4]. While incumbent actors suffer a lack of trust from the public [5], the implementation of decentralized renewable energy installations and smart metering technologies as well as many energy efficiency measures need to be steered by trustworthy individuals and organizations rooted in local communities. Community energy enhances social acceptance of technologies at the local level, as evidenced by comparative research for the case of wind power [6, see also 7]. Moreover, it is linked to identification processes in rural areas and can be interpreted as an expression of more participation in decision-making on this vital infrastructure [8]. Against the background of these findings on the possible economic, social and political impacts of community energy, we focus on the conditions under which a specific form of community energy - wind power cooperatives - emerges.

Renewable energy (RE) cooperatives in general enable citizens to collectively own and manage RE projects at the local level [9, 10]. From an economic standpoint, cooperatives present a different model of ownership than conventional business organizations. Unlike capitalist corporations, they are owned by their members/users rather than investors. In addition, net earnings are usually divided pro rata among the members - not according to their shareholding - but according to the volume of transactions they have conducted with the firm. 
In addition, when part of the net income is allocated as a return on capital shares, such profit distribution is subject to a cap, which means maximization of return on capital may not be a key objective. Finally, they present a democratic governance structure, which involves equal individual voting rights and the absence of barriers to entry for new members.

However, the weight of the RE cooperative sector varies enormously across Europe. While the RE cooperative model is well-established in some countries, it remains marginal in others. In this article, we conduct a comparative analysis of the contextual factors that affect its development in four countries, focusing on the case of onshore wind power: Denmark, Germany, Belgium and the UK. The analysis highlights how different factors combine to facilitate or, conversely, hinder, the development of RE cooperatives. We emphasize the common patterns that emerge from this trans-national comparison without neglecting national specificities. One important pattern observed in these countries can be described as a double movement. The first side of the movement is a convergent observation of an increasingly more hostile environment for cooperatives, a fact which puts them at a relative disadvantage compared to conventional actors. The second side of the movement is a process of strategic reaction from the part of cooperatives, which consists in the emergence of inter-organizational coordinated actions among RE cooperatives in Denmark, Germany and Belgium, such as the creation of joint electricity supply or trading companies. These joint initiatives are the result of strategic responses of small players to regulatory changes and enable them to survive in increasingly hostile environments.

\section{Analytical framework}

Large differences in the development of RE cooperatives have been observed among European countries. Various factors have been explored to explain such disparity. Formal institutional rules, such as support mechanisms for renewables and spatial planning, along with societal norms including attitudes towards the cooperative model and cultures of local energy activism, have been identified as major influences on the occurrence of locally owned community energy $[11,12,13,9,14,7]$. Other explanations include (bio-) physical conditions, and the actors' ability to act strategically to changes in their environment. Finally, it has recently been argued that it is meaningful to investigate how these factors interact in a systemic fashion rather than studying them in isolation $[1,15,16]$. The so-called "SocialEcological System" Framework may be helpful in this task. 


\subsection{The energy system as a social-ecological system}

In a recent article, Hodbod and Adger [15] argue for framing energy systems as socialecological systems. In this perspective, we build the conceptual framework of this paper using insights from the Social-Ecological System (SES) Framework developed by Elinor Ostrom and her collaborators [17]. The SES framework has traditionally been used to study the interactions between the biological basis of ecosystems and social processes. However, recent expansions of the framework make it applicable to questions of the governance of humanly designed technological systems, such as energy infrastructures [18]. The center of this framework is constituted by an "action situation", in which multiple actors interact with each other under the influence of different contextual variables. These interactions produce outcomes, which are linked to contextual variables through feedback paths (see fig. 1).

Figure 1. Graphical representation of the social-ecological framework.

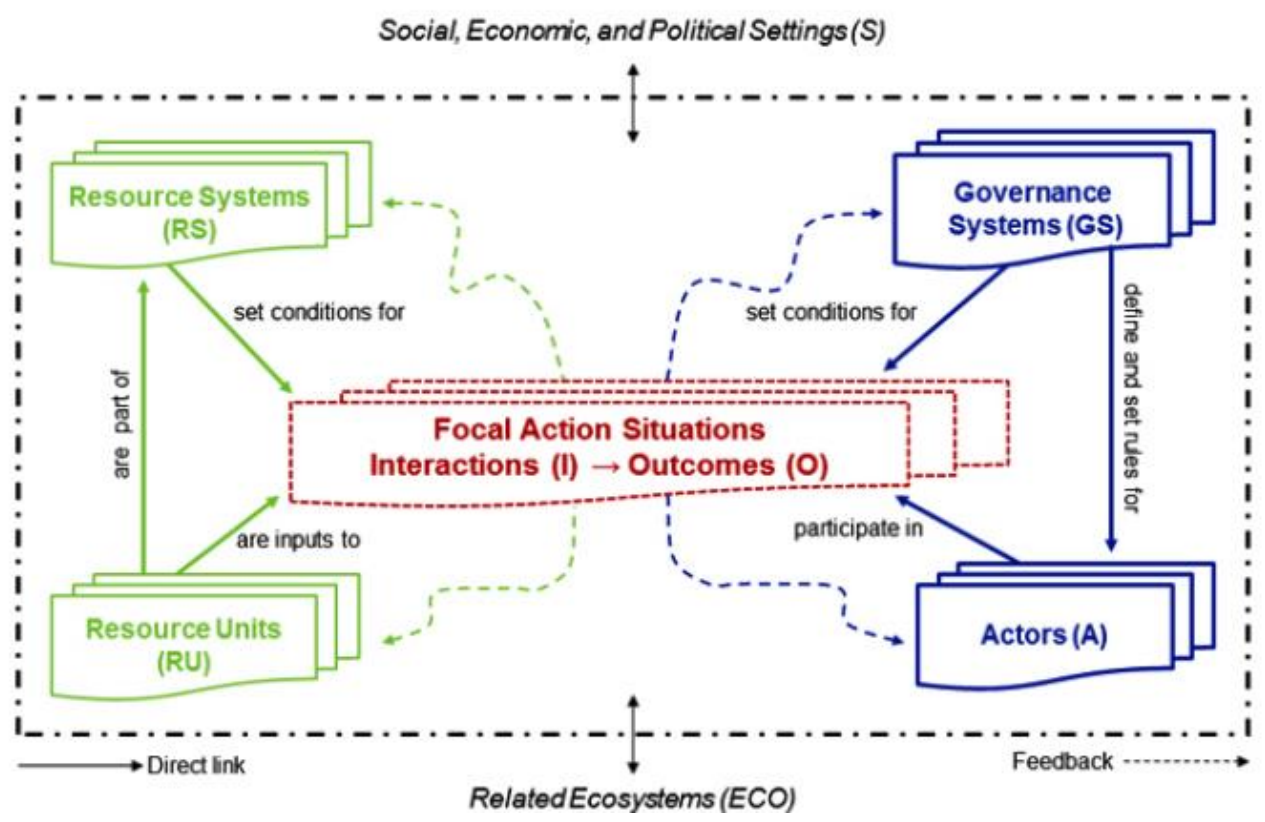

Source: McGinnis and Ostrom [18].

Contextual variables include Resource Systems, Resource Units, Governance Systems and Actors. Resource systems designate the biophysical/technical systems from which Resource Units are extracted. These Resource Units can then be consumed, used as inputs in a production process or exchanged for other goods and services. Governance Systems include "the prevailing sets of processes or institutions through which the rules shaping the behavior of the [actors] are set and revised" [19: 181]. Actors are individuals or collective entities who participate in relevant action situations and are defined by some shared attribute(s), such as 
leadership, social capital, access to technologies, management skills, etc. Social, Economic, and Political Settings and Related Ecosystems respectively represent the broader social and ecological contexts that may influence the focal SES exogenously.

Hence, the SES framework has the advantage of embracing and integrating into one logical entity different approaches: approaches based on agency, which focus on the thoughts and actions taken by actors expressing their individual power in social contexts, and approaches oriented toward structure, which focus on the set of broader social forces and institutions which constrain the choices made by actors. Finally, the framework also sets the biophysical/technical boundaries in which social interactions take place.

\subsection{Application of the SES framework to the case of energy systems and RE cooperatives}

The factors influencing the development of RE cooperatives involve action situations and actors at multiple levels. For instance, most support instruments for renewables are designed at the national level, while, in the case of wind power, planning regulations are usually located at the regional or local level. The case here is thus characterized by a multi-level or polycentric system [1]. Yet for the purpose of this article, we consider countries as the main geographical area of analysis. The outcome that is relevant for our inquiry is the pattern of occurrence and success of RE cooperatives operating on national power markets.

Regarding Resource Systems and Resource Units, energy systems can be subdivided into two major types of resource systems: biophysical resource systems and technical resource systems. Biophysical resource system variables encompass the type and abundance of primary energy resources, their location, etc. Technological resource system characteristics cover the type and size of technology, the distance from the grid, the intermittency, the storage capacity, and many other factors.

In this article, we are primarily interested in the structural factors, i.e. Governance Systems variables which influence the patterns of appearance and success of RE cooperatives. We consider Resource Systems and Resource Units essential background factors. On the other hand, while idiosyncratic features of RE cooperatives may account for differences between organizations, they are unlikely to explain why this sector displays different degrees of development across the four countries. Yet there are factors under the form of societal norms, such as attitudes towards the cooperative model or cultures of local energy activism, which also play an essential role. We here consider them as Actors variables since these norms exist 
only to the extent that they are embedded in actors. We return to some important interactions between the elements of the SES Framework in the following discussion.

\subsection{Operationalization of Governance Systems and Actors variables}

The SES Framework attempts to identify the fundamental building blocks which need considering when studying SESs and their internal interactions. As such, the framework can be applied to all types of SESs. Yet, to conduct our analysis, it is essential to further specify the factors that are relevant in our case. We have identified four main factors based on the literature and our empirical analysis: two Governance Systems variables (support mechanisms for renewables and planning policies) and two Actors variables (attitudes towards the cooperative model and cultures of local energy activism).

\subsubsection{Support mechanisms for renewables}

$\mathrm{RE}$ cooperatives use RE technologies that are not cost-competitive to conventional technologies for power generation under current power market designs. Support mechanisms have been developed to cope with this problem, which lies at the intersection of Resource Systems and Governance Systems variables. They have stimulated the use of RE technologies by leveling the playing field and making RE projects economically feasible. Feed-in tariffs (FiT), feed-in premiums (FiP) and quota obligations are the most widely used types of mechanism encouraging the generation of electricity by RE sources in Europe. Some authors argue that actors like RE cooperatives are most likely to benefit from risk reducing support mechanisms, which keep transaction costs for financing and operating RE projects low [20]. Indeed, these organizations have limited resources because they rely on their members' equity and external project financing, e.g. bank loans. Moreover, as they focus mostly on one or very few local projects, they are generally risk averse because of constraints to hedge and distribute risks in small portfolios. Whether a support mechanism is market-dependent or marketindependent constitutes an important factor for risk reduction. Market-independent mechanisms like FiTs offer fixed remunerations which are independent of volatile electricity prices and are often accompanied by purchase obligations. This gives high investment security because of predictable cash flows and low transaction costs. Market-dependent mechanisms, such as FiPs or quota obligations, are fully or partly based on volatile electricity prices, which gives producers the incentive to react to price developments and can increase transaction costs for marketing electricity. For small actors like cooperatives, therefore, market-independent mechanisms are generally perceived to be more favorable than marketdependent ones [21]. 


\subsubsection{Planning policies}

Various aspects of planning procedures, which define rules and relevant actors in the operational phase, are likely to affect the development of RE cooperatives. On the one hand, it has been argued that participatory schemes improve the chances of getting planning consent because they can build on local social networks supporting wind power [14]. On the other hand, the small scale of cooperatively-owned projects increases the relative planning risk, especially if planning requirements are not differentiated depending on the size of the project. In addition, RE cooperatives may find it more difficult than large-scale players to afford the failure of planning applications due to lack of resources; they may therefore be more reluctant to engage in projects in the first place. Legal obligations for developers to open the capital to citizen participation may help overcome this obstacle.

\subsubsection{Attitudes towards the cooperative model}

The extent to which a society is familiar with the cooperative model is likely to play a role. In countries where the cooperative movement has an old and well-established tradition, people know about this legal structure and are aware of its benefits. In countries where the general public and other actors are less familiar with this model, this low awareness may potentially constitute a "cognitive barrier" [9]. On the other hand, unwelcome experiences with a specific type of cooperative model can constitute a "(negative) historical legacy". Thus, cooperatives may have a negative reputation in some areas. RE initiatives for joint investments will most probably take other forms in these cases.

\subsubsection{Cultures of local energy activism}

Various authors [13, 22, 7] argue that local ownership is related to traditions of energy activism, and particularly to the anti-nuclear movement. Indeed, anti-nuclear activism is often accompanied by increased interest in alternative energy. In the Netherlands, for instance, the origin of wind cooperatives is strongly linked to an anti-nuclear movement, the Dutch Organization for Renewable Energy (ODE) [11].

\section{Methodology}

We have conducted 40 semi-structured interviews with key actors (cooperative managers and board members, intermediary actors, policy makers) in each of the four countries, and carried out an extensive analysis of different types of documents: regulatory reports, legislation regarding RE generation and citizen participation and documents from relevant actors, e.g. 
meeting minutes, annual reports of cooperatives, etc. An overview of the conducted interviews is summarized in table 1.

Table 1. Interviews conducted.

\begin{tabular}{|c|c|c|c|}
\hline Number & Position/ Organization & Country & Date \\
\hline 1 & Cooperative Manager & Denmark & 23.06 .2014 \\
\hline 2 & Consultant/Cooperative board member & Denmark & 10.07.2014 \\
\hline 3 & Researcher/ Cooperative member & Denmark & 27.06.2014 \\
\hline 4 & NGO Manager & Denmark & 08.07 .2014 \\
\hline 5 & Association Board Member & Denmark & 02.07 .2014 \\
\hline 6 & Association Manager & Denmark & 01.07 .2014 \\
\hline 7 & Local Administration Official & Denmark & 27.06.2014 \\
\hline 8 & Bank Manager & Denmark & 09.07.2014 \\
\hline 9 & Company Manager & Denmark & 03.07 .2014 \\
\hline 10 & Public Electricity Company Manager & Denmark & 03.07 .2014 \\
\hline 11 & NGO Director & Denmark & 14.05.2014 \\
\hline 12 & Association Director & Denmark & 01.08 .2014 \\
\hline 13 & Local administration & Germany & 10.05 .2012 \\
\hline 14 & Local administration & Germany & 28.08 .2012 \\
\hline 15 & Local administration & Germany & 05.11 .2012 \\
\hline 16 & Local administration & Germany & 24.08.2012 \\
\hline 17 & Municipal association officer & Germany & 11.09.2014 \\
\hline 18 & CEO municipal utility & Germany & 25.06.2012 \\
\hline 19 & CEO municipal utility & Germany & 03.03 .2014 \\
\hline 20 & Regional wind energy agency officer & Germany & 20.11.2012 \\
\hline 21 & Cooperative association officer & Germany & 06.11 .2012 \\
\hline 22 & CEO wind cooperative & Germany & 22.11.2012 \\
\hline 23 & Biogas plant owner & Germany & 29.01.2015 \\
\hline 24 & CEO windpark SPVs & Germany & 20.09.2012 \\
\hline 25 & CEO cooperative association & Germany & 04.09 .2013 \\
\hline 26 & Cooperative Board Member & Belgium & 04.10 .2013 \\
\hline 27 & Cooperative Manager & Belgium & 04.10 .2013 \\
\hline 28 & Cooperative Manager & Belgium & 06.03 .2014 \\
\hline 29 & Coordinator of an Association of Cooperatives & Belgium & 26.09.2014 \\
\hline 30 & Wind Energy Facilitator for the Walloon Region & Belgium & 14.10.2014 \\
\hline 31 & Cooperative Board Chair & Belgium & 15.10 .2014 \\
\hline 32 & Wind Energy Facilitator for the Flemish Region & Belgium & 17.11.2014 \\
\hline 33 & Cooperative Employee & Belgium & 19.11.2014 \\
\hline 34 & Cooperative Employee & Belgium & 19.11.2014 \\
\hline 35 & Cooperative Board Member & Belgium & 20.11.2014 \\
\hline 36 & Independent Researcher on Community Energy & The UK & 30.05 .2014 \\
\hline 37 & Cooperative Energy Activist & The UK & 06.06 .2014 \\
\hline 38 & Cooperative Board Member & The UK & 13.06.2014 \\
\hline 39 & Cooperative Energy Activist & The UK & 09.09.2014 \\
\hline 40 & $\begin{array}{l}\text { Policy Maker, Head of Community Energy } \\
\text { Department }\end{array}$ & The UK & 22.10 .2014 \\
\hline
\end{tabular}




\subsection{Case selection}

Several reasons account for our selection of four countries: Denmark, Germany, Belgium and the UK. On the one hand, they correspond to different development stages of the cooperative energy sector (see fig. 2).

Figure 2. Approximate number of renewable energy cooperatives in seventeen European countries, 2014.

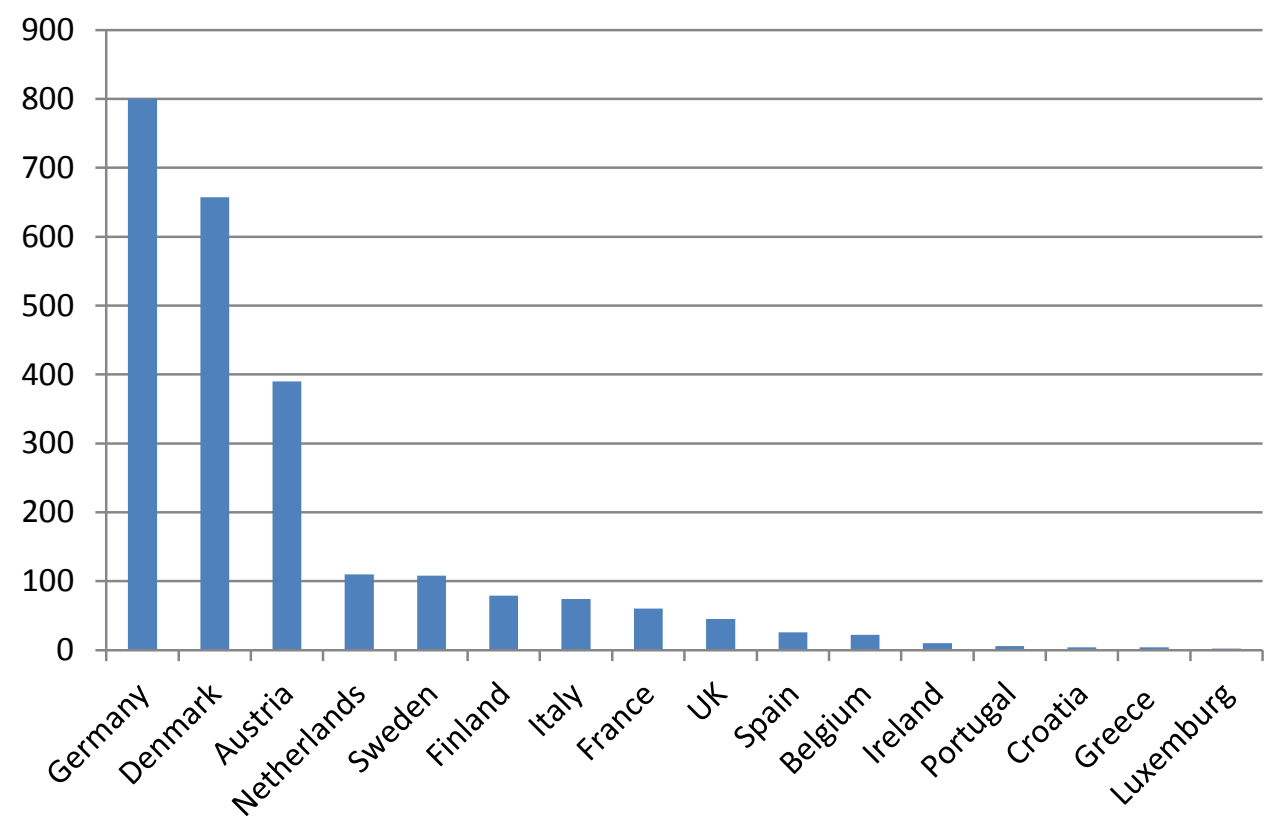

Source: REScoop.eu.

While in Denmark and in Germany, RE cooperatives are already well established, in Belgium and the UK they exhibit a much lower degree of development albeit promising growth perspectives. These four countries have different main support mechanisms for $\mathrm{RE}$ development: Germany and Denmark have implemented a feed-in tariff whereas the UK and Belgium mainly use a quota obligation system based on the trade of certificates.

\subsection{Data collection}

Although RE cooperatives are but one model of community energy among others, they are the focus of the present study. There are methodological and substantive reasons justifying this choice. Methodologically speaking, looking at the whole spectrum of community energy initiatives would considerably complicate the comparative analysis. In addition, as 
cooperatives are formally registered organizations and benefit from a legal framework in most European countries, they are easier to compare internationally than informal initiatives. Furthermore, the cooperative model is arguably one of the strongest forms of community energy in Europe. At European level, it is indeed the only model that is represented by a federation, REScoop.eu. RE cooperatives are also strongly embedded in the international cooperative movement, an international network of cooperatives and advocacy organizations that aim at promoting and spreading the cooperative principles of solidarity and democratic governance [23]. Furthermore, while the access to finance during the at-risk stage is acknowledged as a barrier to the development of community energy projects [24], cooperatives are a particularly suitable model to ensure the financial viability of small-scale projects through fundraising among community individuals compared to other models depending on grants or loan schemes.

Finally, we concentrate on one technology, onshore wind power, because it is the technology that is most commonly developed by cooperatives across the four countries studied. Wind power is also characterized by high technical potential and has a major role to play to reach European renewable targets. In addition, focusing on one technology greatly facilitates the comparison between countries.

\section{Findings about the four countries concerned}

\subsection{Denmark}

\subsubsection{Background}

Denmark is a pioneer in wind power, the development of which is closely connected to cooperatives. These are formally organized as general partnerships where individual citizens invest jointly in the procurement of wind turbines to operate them and sell the electricity output. In 2002, cooperatives owned slightly less than 40 percent of the total number of 6,300 turbines installed, and over 150,000 households owned shares in wind power cooperatives. The remaining turbines were owned by single owners (approx. 40 percent) - mostly farmers and utilities (approx. 20 percent) [25]. By 2004 the number of households owning shares in cooperatives had decreased to 100,000 and by 2009 to 50,000 [26]. The number of new wind turbine cooperatives after 2009 is difficult to quantify but new wind power projects mostly 
tended to be developed and owned by utilities and professional project developers. ${ }^{2}$ The Danish Wind Turbine Owners association (DK VIND) estimates that by 201015 percent of all turbines in Denmark were owned by cooperatives [27]. An expert estimates that in 2014 there were still 300-400 wind power cooperatives with local people holding a majority of shares (interview 2).

\subsubsection{Support mechanisms}

Historically, the main support mechanisms available were investment grants for wind turbines from the Danish state in the 70s and 80s, tax exemptions for income from wind turbines and, from the mid-1980s, fixed feed-in tariffs including guaranteed grid connection, purchase obligations and priority transmission for wind power producers $[12,28]$. Tax exemptions and FiTs created a high investment security for wind projects by guaranteeing stable incomes and financing from banks was available at reasonable interest rates (interview 3).

After a reform of the electricity sector in 1999, Denmark enacted new rules for wind power support. Wind turbines authorised between 2000 and 2002 as well as those already in operation received a 25 percent lower FiT and payment duration was limited. This reduced economic feasibility for new wind projects and the occurrence of new cooperatives was slowed considerably. The support mechanism was drastically changed in 2003. After the election of a new liberal-conservative government, Denmark implemented a fixed FiP scheme in 2003. Producers received the Nord Pool market price ${ }^{3}$ and a fixed maximum premium. Moreover, all new producers had to market their electricity directly on the wholesale market.

Consequently, between 2003 and 2008, there came no new cooperatives while many existing ones dissolved. The main reason was that the premium was too low to compensate for low Nord Pool wholesale prices, and price volatility was perceived as a big risk by ordinary citizens and thus "scared people to enter into the cooperative game" (interview 1). Meanwhile, the government had set up attractive incentives for decommissioning and repowering old turbines, which were often owned by cooperatives. After receiving good offers, many cooperatives dissolved and sold off their turbines to commercial actors. "[...] there was a tendency that the bigger developers were the only ones who could deal with these problems" (interview 7).

\footnotetext{
${ }^{2}$ Ownership in wind turbines was centrally registered in Denmark until 2001. There has not been official government data on ownership groups ever since and the figures presented here are based on the available literature and expert interviews.

${ }^{3}$ Nord Pool is a common electricity spot market between Scandinavian and Baltic countries. Denmark joined the exchange in 2000 .
} 
In 2009, the support mechanism was reformed again when the Danish government enacted the Promotion of Renewably Energy Sources Act of 2009 (REA 2009). The fixed premium payment was increased, which, as to several interviewed experts, made cooperative wind projects economically feasible again. However, with increased turbine sizes, capital investments for wind projects have also increased. Due to price volatility under the Danish FiP, financing cooperative wind power projects has remained challenging after 2009. Cooperatives have thus increasingly sought alternative funding resources [29]. One of these was the creation of a trading company called Vindenergi Danmark, which purchases and trades electricity at Nord Pool on behalf of wind power cooperatives and other private producers. Vindenergi Danmark is organized as a non-profit cooperative owned exclusively by its members. Even though there are no exact figures, it is estimated that two thirds of all cooperatives trade with Vindenergi Danmark (interview 9).

\subsubsection{Planning policies}

Denmark is the only of the four countries considered here to have from the outset promoted the ownership of wind power by local citizens, companies and cooperatives through planning schemes and specific regulations.. Around 2000, in fact, cooperatives, single owners and farmers owned 80 percent of all wind turbines in Denmark because the government restricted ownership of wind turbines to local actors living or being registered in geographical proximity to the turbine they owned [12]. Restrictions were completely deregulated after 1999, which opened ownership to commercial actors such as foreign companies, and initiated the commercialization of wind power in Denmark.

Spatial planning was also reformed in 1999 in reaction to the growing impacts from larger turbines and the decreased availability of designated sites for wind power. Costs for planning increased after the reform because procedures became more restrictive and lengthy due to higher requirements. This factor and the arrival of more professional actors became considerable obstacles for new cooperatives because commercial actors were able to pay higher prices and act faster than cooperatives with democratic decision-making (interview 12). Consequently, local ownership had suffered a drawback since the early 2000s and "it became clear that it is quite a challenge to obtain local acceptance if wind power development is only driven by professional developers or by large energy companies" (interview 4).

In 2007, the Danish government started to observe stagnation in wind power and increasing local resistance against wind projects as problematic. To restore and maintain public acceptance, the Danish government enacted specific regulatory measures to proactively 
ensure citizen ownership in wind power projects. Under the REA 2009, a local citizens' option to purchase wind turbine shares was implemented, thereby compelling developers of a new wind turbine to offer at least 20 percent of the ownership to local citizens living within a radius of $4.5 \mathrm{~km}$ from the turbine. On the other hand, a public guarantee fund was established to support the financing of preliminary investigations, planning, etc. by local wind power cooperatives.

\subsubsection{Attitudes towards the cooperative model}

Historically, Denmark has a long tradition of cooperative enterprises. The first cooperatives were established in the agricultural sector and became one of the widest spread forms of commercial activities in the country during the first half of the $19^{\text {th }}$ century. To this day, cooperatives have been a common feature in Danish life, and can be found in many sectors, e.g. food industry and retail, but also in public services such as consumer owned energy utilities. Even though many cooperative enterprises in rural areas suffered a drawback in the 1970s, principles of solving problems collectively at the local level and establishing vehicles for cooperation, such as e.g. cooperatives, have remained widespread in Danish society. So, when wind power technology became commercially available in the 1970s this fell on a fertile cultural soil for the cooperative model.

\subsubsection{Local energy activism}

Denmark is characterized by a strong tradition of local energy activism. Anti-nuclear protests and grassroots activism experimenting with alternative ways of producing energy go hand in hand. On the one hand, these voices can be traced back to the strong and well-organized Danish anti-nuclear movement, which was able to influence policy towards support for RE [29]. On the other hand, grassroots actors - individuals, farmers or local citizens organized in cooperatives - actively engaged in developing alternatives: they set up wind turbines on their properties, fought for grid connection and support from government, shared experiences and cooperating with a nascent manufacturing and servicing industry for wind power (interview 12).

Another important driver for local energy activism and cooperative initiatives is local added value through wind projects. Historically, wind power development in Denmark was based on the principle that those having to bear the impacts of wind turbines should also enjoy their benefits. This principle was challenged after 2000 by the commercialization of wind power, when actors external to local communities started implementing wind projects. This trend triggered local resistance against wind projects when local citizens felt excluded from 
decision-making and economic benefits (interview 11). Today, there are more than 200 local groups opposing wind power [30].

\subsection{Germany}

\subsubsection{Background}

Germany, like Denmark, is a leading country in RE deployment within Europe. Onshore wind power has been the dominating RE technology with around 50 percent of all RE sources. Community ownership is estimated to have a share of around 20 percent in this segment of the market [31]. In the initial phases of the wind energy sector, this share has even been much higher. ${ }^{4}$ The decrease in the share of community energy may be explained by the trend toward professionalization and commercialization in this sub-sector of the energy market [32]. The most common legal form for community wind is the limited partnership with limited liability company as general partner $(\mathrm{GmbH} \& \mathrm{Co} . \mathrm{KG}$, henceforth: limited partnership model). The main difference with the cooperative model is that usually voting rights are allocated according to the amount of capital invested in the limited partnership model, i.e. the cooperative democracy principle does not apply. Although cooperatives have experienced a rapid growth in recent years-there are around 973 energy cooperatives, among which 82 are active in wind [33] - they are mostly active in solar generation, as the latter yield comparatively higher returns.

\subsubsection{Support mechanisms}

The German support system has played an essential role in the development of the German RE market and contributed to its highly diversified actor structure in power generation [12, $32,7]$. Both RE development and small actors have been favored by stable instruments since 1991. Another essential step was the enactment of the Renewable Sources Act (German: Erneuerbare-Energien-Gesetz, EEG) in 2000, which granted RE power plants fixed tariffs combined with priority feed-in. This considerably reduced market risks and guaranteed investment security. Loans at preferential conditions and associated refinancing possibilities by Deutsche Ausgleichsbank, now Kreditanstalt für Wiederaufbau (KfW), constituted an additional favorable factor and helped develop a stable and broad base within the banking sector, especially also through local banks in coalitions with other local actors.

Since 2012, RE plant owners have had the possibility to directly market their electricity and receive the difference between fixed tariff and average exchange price - the so-called "market

\footnotetext{
${ }^{4}$ Bolinger [12] cites a figure of three quarters.
} 
premium" - from grid operators. This FiP system has been compulsory since the 2014 amendment of the EEG. Due to transaction costs and economies of scale with a resulting minimum size of the portfolio needed, it is difficult for small actors to enter the electricity sales market, which is dominated by few actors with large market shares [34].

\subsubsection{Planning policies}

We highlight two aspects of the planning procedures. First, Germany has planning procedures somehow making wind energy projects calculable despite prevailing risks linked to environmental assessments and to the pressure of anti-wind groups. Second, there is widespread support for the idea of community ownership at the local level despite the incapacity of municipalities to legally enforce it.

The planning phase in Germany usually takes three to five years for wind energy projects. For this phase, risk capital is needed which is usually available in energy cooperatives only at a very limited scale. Yet, there have been several solutions developed in praxis involving either supporting structures such as joint ventures of smaller actors like energy cooperatives or the involvement of third parties like developers or utilities [35]. Priority and suitability areas for wind power plants are designated by local authorities and differ in restrictiveness between regions or even within a region (interviews 14-17). Similar differences can be observed with regard to the increasingly well organized "anti-wind" movement which interacts with local authorities (interview 18), but seems to be less strong in some areas with high penetration of community wind (interview 21). In general, the problem of cooperative wind energy projects seems to be not so much with planning procedures, but rather with securing the acquisition of land tenure [35] and-at least until recently-with investor protection legislation [36]. "THE problem is to acquire the properties at the beginning, and the land owners are so greedy and the external developers [...] offer such high rents [...] But they offer 8-12 percent at the beginning, so that a community initiative does not get hold of the properties" (interview 21).

Local regulatory and planning authorities in some regions also try to actively promote community ownership (interviews 13, 14) because of the supposed positive effects on acceptance, even if this is contested or relativized by some interviewees (interviews 18, 19).

\subsubsection{Attitudes towards the cooperative model}

Modern cooperatives have a long tradition in Germany. In some areas, however, there have been negative experiences with rural cooperatives, due to prevailing skepticism about the cooperative model. Cooperatives have been regarded as "old-fashioned" and knowledge of 
the legal form declined, at least until the marketing campaigns led by cooperative associations in connection with the 2006 amendment of the Cooperative Societies Act [38].

The rise of the new energy cooperative model coincides with the financial crisis and a search for new economic models. In this context, the cooperative model as a democratic legal form has been considered to be the ideal legal base for this movement. The higher share of wind cooperatives in southern Germany compared with the northern part may at least partly be explained by the coincidental financial crisis and development of wind energy in Southern Germany - despite prevailing tax advantages for the KG model (interview 21).

Two regions known for a traditionally strong cooperative movement, namely Weser-Ems and Baden-Württemberg, stand out among clusters of developing energy cooperatives. A similarly conducive institutional environment seems to exist in Frankonia (the northern part of the federal state of Bavaria). Energy cooperatives are less developed in the Eastern part of Germany, owing to the socialist era's possibly negative legacy as well as to a financially worse-off population (interview 21).

\subsubsection{Local energy activism}

From the end of the 1980s and the beginning of the 1990s, Germany has been a strong antinuclear movement as part of the broader environmental movement which supported the development and deployment of RE technologies [39]. This activism within advocacy coalitions seems to play a role in many bottom-up initiatives including such energy cooperatives. Yet, such legal forms differ despite the essential closeness of the movement to the cooperative idea, as the distribution of the limited partnership model in Northern Germany shows [39]. Nor can the strength of the anti-nuclear movement explain the differing distribution of energy cooperatives across Germany. These are not necessarily located in the centers of the anti-nuclear movement. The environmental movement in East Germany, which today has fewer energy cooperatives, also articulated critique against nuclear power at about the same time as in West Germany [40].

Moreover, it seems that there is a mixture of motivations behind joint investments in wind power. Profitability expectations have been playing a higher role in Germany than elsewhere $[12,32]$. Advocacy coalitions in wind power have reached beyond the anti-nuclear movement and included interested engineers, farmers and other small firms. Along with a process of professionalization, stronger competition over sites, and higher rent expectations by 
landowners, this stronger profit-orientation may also hinder the development of cooperatives in some areas (interview 21).

\subsection{Belgium}

\subsubsection{Background}

Electricity generation in Belgium is still clearly dominated by Electrabel, the incumbent company and former state monopoly. A similar situation prevails on the electricity supply market. In Wallonia, there are 19 RE cooperatives ( 9 of which are already active) and 6 local citizen associations, i.e. organizations supposed to be upgraded to cooperatives in the future. In Flanders, there are $5 \mathrm{RE}$ cooperatives and 3 local citizen associations. This, for the country as a whole, gives a total of $23 \mathrm{RE}$ cooperatives and 11 local citizen organizations. They are all active in wind, although some develop other technologies as well. Walloon cooperatives represent 4.6 percent of wind power installed capacity [6], while the two largest Flemish cooperatives represent about 4 percent of total wind power installed capacity in Flanders. Most initiatives are volunteer-based. These figures suggest that the cooperative energy sector is still marginal. The case of Belgium is interesting, though, because these cooperatives count pioneers, such as Ecopower which is one of the largest cooperatives in Europe in terms of membership.

\subsubsection{Support mechanisms}

Electricity from RE sources is given priority in both connection to and use of the grid. In addition, it is promoted mainly through a quota system based on the trade of certificates. In general, RE is a regional matter; only offshore wind power and hydro power are governed by national regulations. Therefore different frameworks exist in the country to support the development of RE sources, but the general mechanism of green certificates is common to all regions. According to the Social Economic Council of Flanders, the green certificate system favors incumbent, large scale energy producers to the detriment of new and more participatory initiatives [41]. Existing, large electricity producers and suppliers have an advantage over new players because they can easily develop cheap RE production by burning biomass in existing coal plants. Getting a permit for a new biomass power plant or wind turbines is far more difficult. This tendency of green certificates to favor incumbent actors was highlighted by different practitioners: "Green certificates have been implemented to encourage green energy projects. But again, these big consulting firms quickly analyzed the situation, and Electrabel converted the Awires [coal] plant to burn pellets... [...] Green certificates had been invented to oblige big companies to change their ground, but they 
continue exactly the same way" (interview 26). In recent years, the green certificate systems have undergone deep changes, both in Flanders and in Wallonia, which resulted in a steep decrease in the value of certificates. These changes have had important consequences for RE producers, including cooperatives, whose income declined steadily (interviews 26-28, 33, 34).

To be able to compete on the supply market, 6 wind cooperatives in Wallonia in 2013 jointly created a supply company, named Cociter. This is constituted as a cooperative and purchases the wind power generated by its members. By doing so, cooperatives benefit from economies of scale and reduce transaction costs because obtaining a supplier license requires to fulfill various economic and technical conditions.

\subsubsection{Planning policies}

The Belgian institutional context is not particularly conducive to cooperative initiatives. In Flanders, for instance, Pepermans and Loots [42] note that wind power has been developed following a top-down fashion, while bottom-up emergence is an exception. One problem emphasized by several interviewees is the "first-come, first-served" system prevailing in wind siting processes in both regions. This means that authorities address the permit requests in chronological order. This policy, combined with the scarcity of suitable sites, the increasing number of wind developers and the zoning policies of the competent authorities, have created a highly competitive environment and encouraged a "wind rush" on the available locations. In this context, cooperatives lack the time and resources to act as fast as large-scale wind power producers [42]. Since 2011, less new wind projects have been realized, especially in Wallonia, due to the increasing number of juridical appeals against wind power projects. To counter this trend, new regulation adopted in 2013 by the Walloon government makes it compulsory for wind farm developers to open the capital of any new project up to 24.99 percent for citizen participation and to 24.99 percent for municipalities' participation [6].

\subsubsection{Attitudes towards the cooperative model}

With origins going back to the mid- $19^{\text {th }}$ century, the cooperative tradition in Belgium is by no means new. However, contrary to what occurred in most other European countries, the essential cooperative principles were forgotten during the creation of the legal identity of cooperatives or, more specifically, "compliance with them was simply considered optional" [43:5]. As a result, two kinds of cooperatives have since co-existed: the ones implementing the cooperative principle; the others not sharing the cooperative ideal but adopting the cooperative status for its convenience. A similar division can be traced concerning RE cooperatives, because different investor-owned power companies, including the Belgian 
incumbent company, created their own cooperative firms to increase citizen participation in wind power projects. However, a detailed examination of the statutes of these "top-down" initiatives clearly shows that the business purpose of these cooperatives is the acquisition of a cooperative capital to finance RE production plants by granting loans to the companies actually owning and operating the assets. Hence, cooperative members do not actually co-own wind turbines, which remain the property of these operating companies- generally the parent power companies or one of their subsidiaries. The emergence of these organizations is a challenge for "bottom-up" cooperatives and forces them to emphasize their specificities to acquire legitimacy. In this perspective, "bottom-up" RE cooperatives gathered into a national federation, REScoop Belgium in 2013, which was split into two regional sections the year after. Belgian cooperatives and, notably, Ecopower, have been instrumental in the creation of the Federation at the European level, REScoop.eu.

\subsubsection{Local energy activism}

Anti-nuclear mobilization in Belgium has remained marginal and failed to convince the public [44]. Still, several cooperative administrators interviewed confirmed that their activity had, at its origin, a link with local protest movements against nuclear waste or nuclear energy. " [...] there was a project of nuclear waste repository, people mobilized to reject it and contacted local associations of environmental protection to help them organize conferences to oppose the project [...] we organized a conference about the possibilities of going without nuclear energy $[\ldots]$ and one of the solutions that were suggested in the area was wind turbines" (interview 26). Hence, some cooperative initiatives seem to be linked to local anti-nuclear activities, however small.

\subsection{The UK}

\subsubsection{Background}

The UK is one of the best locations for wind power in the world. Despite this favorable endowment in natural resources, the cooperative energy sector is underdeveloped as compared to Germany or Denmark. In 2011, there were 19 RE cooperatives which wholly owned a generation capacity of $19.6 \mathrm{MW}$ and had part ownership in a further $1.22 \mathrm{GW}$ of capacity through investment in larger, commercial schemes. Eight organizations were at launch stage and a further 16 were in the process of or planning to undertake feasibility studies [45]. The UK's energy sector is biased toward large scale facilities and corporate ownership. Most energy supply in the UK is concentrated into six large companies, known as the "Big Six": British Gas, EDF, E.On, nPower, Scottish Power and Scottish and Southern Energy. Only 0.3 percent of the generated 
electricity does not originate from these utilities. This probably explains the leading role of the UK in offshore wind power generation, since "the nature and scale of offshore wind implies that their development is concentrated in the hands of utilities rather than individuals or communities" [24:545]. The UK has a much smaller capacity of onshore wind power, the ownership of which is also dominated by utilities.

\subsubsection{Support mechanisms}

In the UK, the generation of electricity from renewable sources has originally been incentivized through Renewable Obligation (RO), a quota system that compels electricity suppliers to prove that a certain proportion of the electricity supplied was generated from renewable sources. Various scholars argue that this system and its predecessor, the "Non Fossil Fuel Obligation", are responsible for the lack of diversification in terms of scale and ownership structures [12, 13, 24]. A Feed-in tariff scheme was launched in April 2010 and targets RE plants with a capacity of up to 5MW. It aims at protecting new scales and ownership schemes from the more competitive environment created by the RO, which had led to few large actors. In his study on the roles of the FiT in community energy development, Nolden [24] however notes that, while the FiT presents positive effects for community-led development, such as a lower dependence on grants, this isolated measure is unlikely to modify the dominant policy framework centered on large-scale developments. This is confirmed by several interviewees. For instance, one expert states: "it still doesn't really fit the system [...] there is strong political support for [community energy], from all parties, but it's not changing the rules of the system, which is still very much designed for these big players" (interviews 36).

The UK has developed an ambiguous position toward cooperative energy. On the one hand, it has actively sought, in recent years, to promote community-based actions in favor of renewable energy, through several policy initiatives, such as the Community and Renewable Energy Scheme in Scotland or the Assembly's Community Scale Renewable Energy Programme in Wales. In January 2014, the Department of Energy and Climate Change (DECC) launched the Community Energy Strategy, which aims at creating a suitable environment for community-led initiatives to grow and support them to produce, reduce, manage and purchase energy [46]. Practical measures include a £15m Rural Community Energy Fund (RCEF), which was jointly established by the Department for Environment, Food and Rural Affairs (Defra) and the DECC to support rural communities in England to 
develop RE projects. A similar $£ 10$ m fund, the Urban Community Energy Fund (UCEF), was created for urban areas.

On the other hand, in the summer 2014, Her Majesty's Treasury announced that two major incentives to investors currently available to RE projects - the Enterprise Investment Scheme (EIS) and Seed EIS (SEIS) tax relief - would be removed from projects qualifying for the Feed-in Tariff, RO and renewable heat incentive (RHI). SEIS allows a taxpayer who has invested in an eligible scheme to claim back up to 50 percent of his investment in tax relief. This scheme has been used by some community energy schemes to offer considerably higher returns overall to investors. A different relief scheme will be available, but not for companies registered as cooperatives.

\subsubsection{Planning policies}

There has been consistent evidence that planning procedures in the UK represent a considerable burden for onshore wind power development as compared to other countries, both in terms of planning delays and high planning application failure rates [14, 47, 48]. In addition, the planning requirements in terms of imposed delays and negotiation costs are disproportionately demanding for small-scale projects as compared to large-scale developments [49].

As regards measures favoring shared ownership, according to Pollitt [50: 38], "there has been an unwillingness to actively involve communities in co-ownership of onshore wind developments, possibly because of the dominance of large power companies in the UK within the wind power sector and the high transaction costs of such engagement". However, authorities seem to be willing to change this situation. With the publication of the Community Energy Strategy, the Secretary of State for Energy and Climate Change asked the renewables industry and the community energy sector to work together to establish a voluntary Framework to guide shared ownership of RE. A taskforce was established in 2014 to develop such framework and published its final Shared Ownership Framework [51]. So far, however, the initiative is still embryonic and dissensions exist between community energy groups and the energy industry regarding the percentage that developers should offer (interview 40).

\subsubsection{Attitudes towards the cooperative model}

A key reference point in the first wave of cooperative development is the Rochdale Society of Equitable Pioneers, which was founded in 1844 north of Manchester by a group of weavers. Bolinger [12: 50], however, notes, that despite this pioneering effort, "the use of cooperatives has not permeated UK society to the same degree as other European countries such as 
Denmark and Sweden". The UK does not have a specific cooperative law, so almost any legal business form can be structured along cooperative principles. So far, though, RE cooperatives have mainly been formed as industrial and provident societies (IPS). An IPS is an organization that conducts an economic activity either as a "bona fide" cooperative (BFC) or a "society for the benefit of the community" (Bencom). IPS are registered under the Cooperative and Community Benefit Societies Act 2014 and are administered by the Financial Conduct Authority (FCA). The latter institution seems skeptical about the cooperative model in the field of energy. In 2014, the FCA blocked a number of RE cooperative applications on the grounds that members would not participate enough in these organizations. Indeed, FCA rules require a BFC to show participation which it lists as "buying from or selling to the society", "using the services or amenities provided by it" and "supplying services to carry out its business" [52]. Directly supplying electricity from a wind turbine to members would be the most natural way for RE cooperatives to establish such a commercial participation. Yet, UK regulation is such that $\mathrm{RE}$ cooperatives are too small to apply for supplier licenses. According to community energy activists (interviews 37, 39), the refusal of the FCA to register RE cooperatives as BFC could be harmful to the sector, because this legal form is better suited to this model than the Bencom legal form. This is because "BFCs can pay a co-operative dividend which some see as central to the success of a community consumer model, whereas the treatment of capital and profits in Bencoms is currently a very contentious issue" [53: 3].

\subsubsection{Local energy activism}

Historically, grassroots initiatives based on local energy generation as well as a militant antinuclear movement were virtually non-existent in the UK [22]. Rather, a strong tradition of landscape and nature protection activism has inspired opposition to wind projects [13]. This lack of local energy activism may offer an additional explanation for the low number of wind power installations based on local ownership.

Table 2 presents a synthetic view of the comparative analysis. 
Table 2. Synthetic table

\begin{tabular}{|c|c|c|c|c|}
\hline & Germany & Denmark & The UK & Belgium \\
\hline Support mechanisms & $\begin{array}{l}\text { 1991: first law that allowed for } \\
\text { the feed-in of RES. } \\
\text { 2000:Renewable Sources Act. } \\
\text { Objective: create more stable } \\
\text { investment conditions. } \\
\text { 2014: Replacement of the FiT by } \\
\text { a FiP and obligation to market } \\
\text { electricity directly. }\end{array}$ & $\begin{array}{l}\text { Before 1999: low-risk investment } \\
\text { conditions due to tax exemptions, } \\
\text { fixed FiTs } \\
\text { 2003: establishment of FiP and } \\
\text { obligation to market electricity } \\
\text { directly to wholesale market as } \\
\text { major obstacles to the creation of } \\
\text { new cooperatives. } \\
\text { Since 2009: increase of premiums, } \\
\text { improved investment conditions } \\
\text { and emergence of new } \\
\text { cooperatives }\end{array}$ & $\begin{array}{l}\text { Main support mechanism: quota } \\
\text { system. } \\
\text { 2010: introduction of a FiT for } \\
\text { installations }<5 \mathrm{MW} \text {. } \\
\text { Launch of various programs to } \\
\text { back up the development of } \\
\text { community energy. } \\
\text { 2014: reform of the tax relief } \\
\text { schemes. New tax relief scheme } \\
\text { not available for cooperatives }\end{array}$ & $\begin{array}{l}\text { Quota system based on trade of } \\
\text { certificates: favors incumbent } \\
\text { players to the detriment of } \\
\text { small-scale challengers. } \\
\text { 2011-2012: saturation of the } \\
\text { green certificates market and } \\
\text { decrease in income for RE } \\
\text { cooperatives. }\end{array}$ \\
\hline Planning procedures & $\begin{array}{l}\text { Widespread support for } \\
\text { community ownership at the local } \\
\text { level, even if no specific } \\
\text { instruments to legally enforce it. } \\
\text { Discussion in some federal states } \\
\text { to make participation obligatory. }\end{array}$ & $\begin{array}{l}\text { Ownership restriction of wind } \\
\text { turbines until } 2000 \\
\text { 1999: reform of planning } \\
\text { conditions and new obstacles for } \\
\text { cooperatives due to rise in costs } \\
\text { for planning and increasing } \\
\text { competition. } \\
\text { 2009: obligation for developers to } \\
\text { open capital of new projects for } \\
\text { citizen participation. }\end{array}$ & $\begin{array}{l}\text { Planning requirements } \\
\text { disproportionately } \\
\text { for small-scale projects as } \\
\text { compared to large-scale } \\
\text { developments. } \\
\text { Ongoing discussions to } \\
\text { implement a voluntary } \\
\text { framework for shared ownership } \\
\text { of RE. }\end{array}$ & $\begin{array}{l}\text { Unfavorable planning } \\
\text { conditions for small-scale and } \\
\text { participatory projects: "wind } \\
\text { rush" due to first-come, first- } \\
\text { served system. } \\
\text { 2013: in Wallonia, obligation } \\
\text { for developers to open capital of } \\
\text { new projects for citizen and } \\
\text { municipalities participation. }\end{array}$ \\
\hline $\begin{array}{l}\text { Attitudes toward the } \\
\text { cooperative model }\end{array}$ & $\begin{array}{l}\text { Long cooperative tradition, but } \\
\text { negative experiences with rural } \\
\text { cooperatives in some areas, which } \\
\text { partly explain the choice of other } \\
\text { community energy models. }\end{array}$ & $\begin{array}{l}\text { Long historical cooperative } \\
\text { tradition, including in the } \\
\text { electricity sector. }\end{array}$ & $\begin{array}{l}\text { Cooperative movement } \\
\text { comparatively weaker, despite } \\
\text { pioneering initiatives. } \\
\text { Skepticism of the FCA with } \\
\text { respect to the cooperative model } \\
\text { in the energy sector. }\end{array}$ & $\begin{array}{l}\text { Long historical cooperative } \\
\text { tradition, but co-existence of } \\
\text { "true" and "false" cooperatives } \\
\text { Creation of "top-down" } \\
\text { cooperatives by investor-owned } \\
\text { companies. }\end{array}$ \\
\hline Local energy activism & $\begin{array}{l}\text { Strong anti-nuclear movement, } \\
\text { but cannot explain regional } \\
\text { differences. Higher role played by } \\
\text { Profitability expectations. }\end{array}$ & $\begin{array}{l}\text { Strong and successful anti-nuclear } \\
\text { movement which boosted the } \\
\text { search for alternatives. Tradition } \\
\text { of local added value through wind } \\
\text { projects. }\end{array}$ & $\begin{array}{l}\text { Weak anti-nuclear movement. } \\
\text { Strong landscape and nature } \\
\text { protection activism. }\end{array}$ & $\begin{array}{l}\text { Weak anti-nuclear movement, } \\
\text { but some cooperatives rooted in } \\
\text { local protests against nuclear } \\
\text { wastes. }\end{array}$ \\
\hline
\end{tabular}

\footnotetext{
Source: constructed by authors.
} 


\section{Discussion: a double movement}

The results presented above can be summarized as constituting a double movement. ${ }^{5}$ The two sides of this movement are explained hereafter.

\subsection{The first side of the movement: the tendency towards a more hostile environment}

As the analysis of support instruments and planning policies shows, the first side of the movement is the tendency in the four countries studied towards a more hostile environment for cooperative initiatives; these are put at a disadvantage compared to traditional developers. In Denmark, tax incentives and low-risk investment conditions created by fixed FiTs, combined with ownership restrictions prior to 1999 , contributed to large scale cooperative ownership of wind power until 2000. Since 2003, price volatility under the FiP design and a low premium have been major obstacles for the occurrence of new cooperatives and the survival of existing ones. As such, the Danish institutional context has become more similar to experiences in Belgium and the UK, where market-dependent systems have been in place for many years. The UK seeks to secure the development of community-based initiatives with the introduction of a FiT for small installations, but this measure appears to be very isolated in a context which still favors large-scale players. Germany is experiencing a policy evolution similar to Denmark, but with a delay of five to ten years [54]. The fixed FiT regime was abandoned in 2014 in favor of a more market-dependent FiP scheme, resulting in a slightly higher exposure to volatile electricity market prices and the responsibility of producers to market electricity on wholesale markets. In addition, one German federal state is following Denmark's example to legally enforce the financial participation of citizens in new wind power projects [37]. A similar legislation exists in Belgium but the effectiveness of these instruments in creating new cooperatives or strengthening acceptance has been questioned [6; $30]$.

This increasingly hostile environment is also shaped, to some extent, by the evolution of technological Resource systems characteristics, such as the size of wind turbines. The growing size of wind turbines in the countries studied has had two effects. First, planning regulations have become more stringent and posed additional regulatory constraints on cooperative initiatives due to higher costs and increased complexity for obtaining permits.

\footnotetext{
${ }^{5}$ The expression is borrowed from Karl Polanyi's classical book "The Great Transformation".
} 
These changes in planning procedures in Denmark and Belgium have led to the entrance of more professional and commercial developers, which have discouraged cooperative initiatives. In Germany, this tendency to commercialization of projects is even older and stronger, as the limited partnership model has typically been developed in collaboration with more professional and commercial developers [54]. Second, larger turbines have required higher capital investments. This has also encouraged the arrival of commercial actors because the latter have had advantages due to relatively higher liquidity combined with the capacity to make fast decisions. The arrival of these actors has created more competition for cooperatives to obtain sites for wind power development.

However, our analysis also reveals that these tendencies are not unalterable facts. According to the institutionalist approach adopted in this article, markets are themselves complex institutional arrangements. We also refer to Karl Polanyi [55], who takes the view that the economic sphere and market exchanges are embedded in their social, political, and cultural contexts. Accordingly, conceiving of economic activities regardless of their context is ideological. The set of Governance Systems variables-support mechanisms and planning policies-adopted by a country at some point in time is therefore the outcome of interactions between political and grassroots actors in yet other action situations, located at deeper levels of decision-making. This outcome reflects these actors' energy policy priorities, and partly also the political equilibrium reached at that moment. The case of Denmark illustrates this particularly well. Until 2001, the Danish parliament was governed by a coalition of parties favorable to wind power and renewable energy. This situation, combined with the influence of strong grassroots movements and wind power advocacy groups, led to the "cooperativefriendly" policies during the 80 s and 90 s. In 2001, when a liberal-conservative party came to power, it embraced a neo-liberal approach to energy policy and cut all support for RE sources, which had to stand on their own in the free market.

It appears, therefore, that the development of wind energy cooperatives is ultimately related to issues of power. Yet the framework proposed by Ostrom and her colleagues seems to inadequately acknowledge the role of power and interests in the crafting of institutions. Scholars studying these issues have generally focused on the "fitness" of institutions to the characteristics of the SES. Yet, "besides fitting the SES they govern, institutions also need to be supported by a favourable political, economic and discursive context" [56: 158]. Institutions not only result from the interactions of (boundedly) rational individuals steered by 
monetary or non-monetary incentives; they are also shaped to a large extent by power distribution [57].

\subsection{The second side of the movement: strategic reactions of cooperatives}

The analysis revealed that agency, understood here as the characteristics of actors and their strategic interactions within action situations, also plays an important role. Besides the importance of actors in the design of Governance Systems variables and the roles played by social norms and culture highlighted above, this is clearly reflected in coordinated actions undertaken by cooperatives in the different countries studied. In Denmark, wind power cooperatives and individual owners of wind turbines were able to react strategically to changes of support mechanisms by pooling their resources and setting up the trading company Vindenergi Danmark to take care of electricity sales to the wholesale market. In Southern Belgium, a similar company, Cociter, was created to purchase and directly supply to final consumers the energy produced by cooperatives. The case of Bürgerwerke eG offers a similar example in Germany. ${ }^{6}$

Coordinated actions constitute the second side of the double movement. They reduce transaction costs, increase revenues from electricity sales for producers. By pooling their resources and benefitting from economies of scale from an increased wind project portfolio, cooperatives effectively increase the economic feasibility and investment security for wind projects. Hence, such coordinated actions can be regarded as strategic reactions to new regulations and increasingly unfavorable environments. However, there is a second interpretation of the emergence of coordinated actions, which relates to the issue of power relationships mentioned above. Coordinated actions are not simply about pooling resources and increasing the probability of the economic survival of cooperatives. They are also a way of enhancing their bargaining power in the face of incumbent energy actors. Indeed, the latter are smaller in number, have relatively homogeneous interests and are able to coordinate their substantial resources to resist any change that threatens their interests. In contrast, cooperatives are scattered, generally focus on very local issues and have limited resources and power. Thus, coordinated actions may also be seen as an attempt to reach a more balanced distribution of political power in energy markets, which is still very biased in favor of largescale players. The creation of federations of RE cooperatives at national and European levels

\footnotetext{
${ }^{6}$ Bürgerwerke eG is a fast growing joint venture of currently 28 community energy companies (27 cooperatives and one civil law association) selling electricity from community energy power plants plus hydropower. The overall philosophy is to take over all tasks in this area which cannot be executed by a single local community energy firm.
} 
can typically be interpreted in this way. Finally, it is interesting to note that, just as the cost of creating energy cooperatives is higher or lower depending on contextual factors, the formation of coordinated actions, as a collective-action problem, also entails costs which are affected by institutional and actors variables.

This finding is important for subsequent analysis of decentralized energy systems. While decentralization of governance in energy systems is sometimes conceived as a panacea, the emergence of coordinated actions among cooperative initiatives calls for a more polycentric approach, according to which "various scales need to be taken into account when designing regulatory answers and setting up governance arrangements" [1: 136]. In this perspective, although decentralized energy systems obviously exhibit a strong local component, interorganizational coordinated actions highlight the importance of the ability of local initiatives to transcend their local experience in order to form networks at higher levels and articulate their interests to national and European strategies.

\section{Conclusion}

This article has sought to explain the differences in the degree of development of the wind power cooperative sector in four European countries. We have focused on four explanatory factors, namely support instruments for renewables, planning policies, attitudes towards the cooperative model and local energy activism. Relying on some elements of the SocialEcological System Framework, we have emphasized the systemic interactions between these factors and the multi-level features of energy systems. Our results can be summarized in what we have called a "double movement". In this perspective, our results highlight the existence of coordinated actions among cooperatives. We have shown that these coordinated actions can be interpreted in two ways, which respectively emphasize the economic and political contents of these initiatives. On the one hand, they represent strategic reactions of small participatory organizations to adapt to policy evolutions and increasing competition on power markets. On the other hand, they also constitute a way of establishing networks in order to increase their power in energy markets. In this vision, cooperatives not only adapt to externally imposed regulatory changes but also seek to actively shape these changes toward conditions more in line with their interests.

This study suggests various avenues for future research. First, at the theoretical level, energy systems should be decomposed into multiple action situations connected sequentially or 
simultaneously. We have emphasized at various places that the development of renewable energy cooperatives is a polycentric process, which involves the interaction of actors at different levels of decision-making. The framework developed by E. Ostrom and her colleagues is particularly helpful in this endeavor. In addition to taking into account physical, socio-cultural and institutional characteristics in the analysis of collective action, Ostrom emphasizes the need for citizens' self-organization and participation in the process of crafting resilient, just and democratic institutions. If an elite or a dominant group establishes rules without the consent of local communities, they are not likely to serve the common good. This strongly resonates with the participative and inclusive features of renewable energy cooperatives. Moreover, by putting institutions at the center of her approach, Ostrom insists on the necessity of a deep metamorphosis of our core economic institutions. Communitybased initiatives will not be able to achieve much unless their development is accompanied by deeper changes in the rules of the game. For these reasons, it is argued here that this framework holds great promises for the analysis of the decentralization of the governance in energy systems. Another implication would be to assess more accurately the role of power relationships, both theoretically, within the SES framework, and empirically, in the development of wind energy cooperatives. Third, coordinated actions among cooperatives would deserve further analysis of their functions, the way they are created and the actors they involve. For instance, they likely differ in the extent to which they play a more economic or political function. Some may be more oriented towards economic functions while others primarily exert a political role. It would be interesting to study these distinctions and how they relate to other factors.

\section{References}

1. Goldthau, A., Rethinking the governance of energy infrastructure: Scale, decentralization and polycentrism. Energy Research \& Social Science, 2014. 1(0): p. 134-140.

2. Sims, R.E.H. and R.N. Schock, Energy Supply, in Climate Change 2007: Mitigation of Climate Change. Contribution of Working Group III to the Fourth Assessment Report of the IPCC, B. Metz, et al., Editors. 2007, Cambridge University Press: Cambridge/New York.

3. Stern, P.C., Individual and household interactions with energy systems: Toward integrated understanding. Energy Research \& Social Science, 2014. 1(0): p. 41-48.

4. Seyfang, G., J.J. Park, and A. Smith, A thousand flowers blooming? An examination of community energy in the UK. Energy Policy, 2013. 61(0): p. 977-989.

5. Mumford, J. and D. Gray, Consumer engagement in alternative energy — Can the regulators and suppliers be trusted? Energy Policy, 2010. 38(6): p. 2664-2671.

6. Bauwens, T., Propriété coopérative et acceptabilité sociale de l'éolien terrestre. Reflets et Perspectives de la Vie Economique, 2015. LIV(1):p. 59-70.

7. Toke, D., S. Breukers, and M. Wolsink, Wind power deployment outcomes: How can we account for the differences? Renewable and Sustainable Energy Reviews, 2008. 12(4): p. 1129-1147. 
8. MacArthur, J., Renewable Energy and the Social Economy in Alberta: Prospects for Community Power. The International Journal of Environmental Sustainability, 2013. 8(4): p. 121-130.

9. Huybrechts, B. and S. Mertens, The Relevance Of The Cooperative Model In The Field Of Renewable Energy. Annals of Public and Cooperative Economics, 2014. 85(2): p. 193-212.

10. Yildiz, Ö., et al., Renewable energy cooperatives as gatekeepers or facilitators? Recent developments in Germany and a multidisciplinary research agenda. Energy Research \& Social Science, 2015. 6(0): p. 59-73.

11.Agterbosch, S., W. Vermeulen, and P. Glasbergen, Implementation of wind energy in the Netherlands: the importance of the social-institutional setting. Energy Policy, 2004. 32(18): p. 2049-2066.

12.Bolinger, M., Community wind power ownership schemes in Europe and their relevance to the United States. 2001, Lawrence Berkeley National Laboratory: Berkeley.

13.Breukers, S. and M. Wolsink, Wind power implementation in changing institutional landscapes: An international comparison. Energy Policy, 2007. 35(5): p. 2737-2750.

14.McLaren Loring, J., Wind energy planning in England, Wales and Denmark: Factors influencing project success. Energy Policy, 2007. 35(4): p. 2648-2660.

15.Hodbod, J. and W.N. Adger, Integrating social-ecological dynamics and resilience into energy systems research. Energy Research \& Social Science, 2014. 1(0): p. 226-231.

16.Oteman, M., M. Wiering, and J.-K. Helderman, The institutional space of community initiatives for renewable energy: a comparative case study of the Netherlands, Germany and Denmark. Energy, Sustainability and Society, 2014. 4(1): p. 11.

17.Ostrom, E., A diagnostic approach for going beyond panaceas. Proceedings of the National Academy of Sciences, 2007. 104(39): p. 15181-15187.

18.McGinnis, M.D. and E. Ostrom, Social-ecological system framework: initial changes and continuing challenges. Ecology and Society, 2014. 19(2).

19.McGinnis, M.D., An Introduction to IAD and the Language of the Ostrom Workshop: A Simple Guide to a Complex Framework. Policy Studies Journal, 2011. 39(1): p. 169-183.

20.Mitchell, C., D. Bauknecht, and P.M. Connor, Effectiveness through risk reduction: a comparison of the renewable obligation in England and Wales and the feed-in system in Germany. Energy Policy, 2006. 34(3): p. 297-305.

21.Couture, T. and Y. Gagnon, An analysis of feed-in tariff remuneration models: Implications for renewable energy investment. Energy Policy, 2010. 38(2): p. 955-965.

22.Toke, D., Wind Power, Governance and Networks, in Governing Technology for Sustainability, J. Murphy, Editor. 2007, Earthscan: London.

23.Birchall, J., The International Cooperative Movement. 1997, Manchester University Press: Manchester.

24.Nolden, C., Governing community energy-Feed-in tariffs and the development of community wind energy schemes in the United Kingdom and Germany. Energy Policy, 2013. 63(0): p. 543552.

25.Krohn, S., Danish Wind Turbines: An Industrial Success Story. 2002, Danish Wind Industry Association.

26. Mendonça, M., S. Lacey, and F. Hvelplund, Stability, participation and transparency in renewable energy policy: Lessons from Denmark and the United States. Policy and Society, 2009. 27(4): p. 379-398.

27.Skotte, H., Cooperatives - local and democratic ownership of wind turbines, in Green Thinking in Denmark. 2010, Energinet.dk: Fredericia.

28.Meyer, N.I., Learning from wind energy policy in the EU: lessons from Denmark, Sweden and Spain. European Environment, 2007. 17(5): p. 347-362.

29.Hvelplund, F., Innovative Democracy, Political Economy, and the Transition to Renewable Energy. A full-Scale Experiment in Denmark 1976-2013. Environmental Research, Engineering and Management, 2014. 66(4): p. 5-21.

30.Egelund Olsen, B., Regulatory financial obligations for promoting local acceptance of renewable energy projects, in Renewable Energy Law in the EU, M. Peeters and T. Schomerus, Editors. 2014, Edward Elgar Publishing. p. 189-209. 
31.trend:research Gmb, H. and L. Leuphana Universität, Definition und Marktanalyse von Bürgerenergie in Deutschland. Bremen; Lüneburg.

32.Enzensberger, N., W. Fichtner, and O. Rentz, Evolution of local citizen participation schemes in the German wind market. International Journal of Global Energy Issues, 2003. 20(2): p. 191-207.

33.Müller, J.R. and L. Holstenkamp, Zum Stand von Energiegenossenschaften in Deutschland. 2015.

34.Wassermann, S., M. Reeg, and K. Nienhaus, Current challenges of Germany's energy transition project and competing strategies of challengers and incumbents: The case of direct marketing of electricity from renewable energy sources. Energy Policy, 2015. 76(0): p. 66-75.

35.Holstenkamp, L. and H. Degenhart, Problemfelder und mögliche Lösungsansätze bei genossenschaftlichen Bürgerwindparks: Ressourcenmobilisierung und Projektakquise. Zeitschrift für das gesamte Genossenschaftswesen, 2014. 64(3): p. 185-200.

36.Holstenkamp, L., Local Investment Schemes for Renewable Energy: A financial perspective, in Renewable Energy Law in the EU, M. Peeters and T. Schomerus, Editors. 2014, Edward Elgar Pub: Cheltenham. p. 232-255.

37.Maly, C., Legal Aspects of Local Engagement: Land planning and citizens' financial participation in wind energy projects, in Renewable Energy Law in the EU, M. Peeters and T. Schomerus, Editors. 2014, Edward Elgar Pub: Cheltenham. p. 210-231.

38.Doluschitz, R., et al., Analyse der Neugründungen von Genossenschaften: Ergebnisse einer empirischen Untersuchung im Verbandsgebiet Baden-Württemberg. Zeitschrift für das gesamte Genossenschaftswesen (ZfgG), 2012. 62(1): p. 19-34.

39.Mautz, R., A. Byzio, and W. Rosenbaum, Auf dem Weg zur Energiewende: Die Entwicklung der Stromproduktion aus erneuerbaren Energien in Deutschland; eine Studie aus dem Soziologischen Forschungsinstitut Göttingen (SOFI). 2008, Göttingen: Univ.-Verl. Göttingen. 174.

40.Neubert, E., Geschichte der Opposition in der DDR 1949 - 1989: Univ., Diss.-Berlin, 1997. 2., durchges. und erw. Aufl ed. Forschungen zur DDR-Gesellschaft. Vol. 346. 1998, Berlin: Links.

41.S.E.R. Vlaanderen, Rapport hernieuwbare energie: Informatiedossier voor het debat. 2011, SERV: Brussels.

42.Pepermans, Y. and I. Loots, Wind farm struggles in Flanders fields: A sociological perspective. Energy Policy, 2013. 59: p. 321-328.

43.Defourny, J., M. Simon, and S. Adam, The Co-Operative Movement In Belgium: Perspectives And Prospects. 2002, Brussels: Editions Luc Pire.

44.Koopmans, R. and J.W. Duyvendak, The Political Construction of the Nuclear Energy Issue and Its Impact on the Mobilization of Anti-Nuclear Movements in Western Europe. Vol. 42. 1995. 235251.

45.Willis, R. and J. Willis, Co-operative renewable energy in the UK: A guide to this growing sector. 2012, Co-operatives UK: Manchester.

46.DECC, Community Energy Strategy: Full Report. 2014, Department of Energy \& Climate Change: London.

47.Toke, D., Explaining wind power planning outcomes: some findings from a study in England and Wales. Energy Policy, 2005. 33(12): p. 1527-1539.

48.Toke, D., S. Breukers, and M. Wolsink, Wind power deployment outcomes: how can we account for the differences? Renew Sustain Energy Rev, 2008. 12(4): p. 1129 - 1147.

49. RenewableUK, Small and Medium Wind Strategy. The current and future potential of the sub$500 \mathrm{~kW}$ wind industry in the UK. 2014, RenewableUK: London. 2014.

50.Pollitt, M.G., UK Renewable Energy Policy since Privatisation. 2010, Electricity Policy Research Group: Cambridge.

51.Shared Ownership Taskforce, Shared Ownership Taskforce: Report to DECC. 2014.

52.Financial Conduct Authority, Mutual Societies Information Note. New registrations and conversions: co-operative societies and community benefit societies. 2014.

53.Co-operative UK, Community energy announcements in the Autumn Statement 2014. 2014.

54.Gotchev, B., Market integration and the development of wind power cooperatives in Denmark. Lessons learned for Germany. 2015, Institute for Advanced Sustainability Studies: Potsdam.

55.Polanyi, K., The Great Transformation. The Political and Economic Origins of Our Time. Beacon Press: Boston. 
56.Clement, F. and J.M. Amezaga, Conceptualising context in institutional reforms of land and natural resource management: the case of Vietnam. International Journal of the Commons, 2013. 7(1): p. 140-163.

57.Clement, F., Analysing decentralised natural resource governance: proposition for a "politicised" institutional analysis and development framework. Policy Sciences, 2010. 43(2): p. 129-156. 